\title{
Education for sustainable development
}

\author{
Anca Draghici ${ }^{1, *}$ \\ ${ }^{1}$ Politehnica University of Timisoara, Faculty of Management in Production and Transportation, \\ 14 Remus str., 300191 Timisoara, Romania
}

\begin{abstract}
Education for sustainable development in an intense subject and dissemination of good practices are of tremendous need for actors of academia and for those of vocational education, too. Managers and employees must extend their current skills related to sustainability and become leaders in the field. The article presents the last years' experience on the development of a skills development schema on leadership in sustainability and teaching and educating sustainability. These two training skills and the related training materials have been developed through two international projects and partnerships at the European level: (1) LeadSUS Leadership in sustainability - Sustainability Manager, (2013-1-RO1-LEO05 - 28771) developed from 2013 to 2016 and having impact on a target group consisting of companies' employees (most of them managers); (2) TeachSUS - Teaching and educating for Sustainability, (2018-1-R001KA204-049253) that will be develop from 2018 to 2020 and that will target vocational education and training (VET) actors. After a brief presentation of developed skill cards related to educational programs in sustainable development filed, a critical analysis of the implementation potential will underline the strengths and weakness of the actual educational system of higher education to assimilate and implement the proposals (tested and validated with a significant group of trainees).
\end{abstract}

\section{Introduction}

Education for sustainability has started to be considered as a key topic presented by the since the initiative of UNESCO has been promoted in the last 27 years (started in 1992 during the United Nation Conference on Environment and Development (UNCED) in Rio de Janeiro, Brazil). The topics has been recognized as an urgent on and nowadays education is considered by UNESCO as a top priority, directly linked with the basic human right, determinant of peace building and driver sustainable development [1-2]. Furthermore, UNESCO, as the United Nations' specialized agency for education, is entrusted to lead and coordinate the Education 2030 Agenda, which is part of a global movement to eradicate poverty through 17 Sustainable Development Goals by 2030. Education is related to the specific Goal 4, which aims to "ensure inclusive and equitable quality education and promote lifelong learning opportunities for all". The Education 2030 Framework for Action provides guidance for the implementation of this ambitious goal and commitments [1].

\footnotetext{
* Corresponding author: anca.draghici@upt.ro
} 
Most of the research studies in the literature and international organizations initiatives in the field of education for sustainable development have underlined the importance of transferring the existing needs and frameworks (as competencies maps, skill cards, curricula etc.) into practice by trying to adapt them to the local context [3-7]. The main promotors of such researches and of best practices are the following journals: Journal of Education for Sustainable Development, International Journal of Sustainability in Higher Education and the Journal of Sustainability Education, but the subject is tacked also by other journal (e.g. Journal of Cleaner Production, Sustainability). Furthermore, the debate in the literature has proved that there is a diversity of contexts where education for sustainability takes place but there has been recognized the "power of experience" (life experiences as site visits, internships and service learning in communities, project-based learning, place-based learning, field trip and experience) is of great impact and efficiency [5,8-9].

The present article addresses education for sustainable development, which empowers learners to take informed decisions and responsible actions for environmental integrity, economic viability and a just society, for present and future generations, while respecting cultural diversity. The education in this field is a holistic and transformational one, most transdisciplinary and multidisciplinary. This type of education addresses learning content and outcomes, uses innovative pedagogy and "learning by doing" method, and uses a wholeeducational entity approach to engage communities in achieving sustainable change.

In this context, the article presents the last years' experience on the development of a skills development schema on education for sustainable development in Romania. Two skills development were targeted: leadership for sustainability and teaching and education for sustainability. These two training skills and the related training materials have been developed through two international projects and partnerships at the European level: (1) LeadSUS - Leadership in sustainability - Sustainability Manager, (2013-1-RO1-LEO05 28771) developed from 2013 to 2016 and having impact on a target group consisting of companies' employees (most of them managers); (2) TeachSUS - Teaching and educating for Sustainability, (2018-1-R001-KA204-049253) that will be develop from 2018 to 2020 and that will target VET actors. After a brief presentation of developed skill cards related to educational programs in sustainable development filed, a critical analysis of the implementation potential will underline the strengths and weakness of the actual educational system of higher education to assimilate and implement the proposals (tested and validated with a significant group of trainees).

\section{Literature review}

As stated by UNESCO's documents and reports [1,2], the promotion of quality education is critical for enhancing people's lives and advancing sustainable development. For this reason, the $4^{\text {th }}$ Sustainable Development Goal was established, with a specific target focused on education for sustainable development: "By 2030, ensure that all learners acquire the knowledge and skills needed to promote sustainable development, including, among others, through education for sustainable development and sustainable lifestyles, human rights, gender equality, promotion of a culture of peace and non-violence, global citizenship and appreciation of cultural diversity and of culture's contribution to sustainable development" [10]. Education for sustainable development has been supported by UNESCO different initiatives, and following reports have shown the progresses made and the discrepancies around the World [11]. Education for sustainable development (or the environmental education) has been recognized as an imperative to help plan and prepare the young generation (involved in the pre-university or university education) for the environmental changes in the future. "It is important to inform future generations on ways to meet the 
challenges of climate change issues through education and awareness" [12]. "A sustainable world will only be possible by thinking differently" [13].

Sustainable development touches several disciplines, such as environment, biology, medicine, nutrition, agronomics, geography, engineering, architecture, citizenship, sociology, psychology, political science, history, law, economics and business [14]. Furthermore, reorienting the existing education programmes to include more aspects related to sustainability and its three pillars (society, environment and economy) should be achieved in a holistic and interdisciplinary context, with teachers, trainers weaving sustainability issues into the curriculum [14-17].

In the literature, many studies present the interconnection between education for sustainable development and their associated competencies [18-23]. The main idea underlined by the studies is that key competencies are essential for individuals to transform their own lifestyles and to contribute to societal transformation towards sustainability. Above all, OECD considers three categories of key competencies related to the sustainable development: (1) using tools interactively (the ability to use language, symbols and texts interactively, the ability to use knowledge and information interactively, and the ability to use technology interactively); (2) interacting in heterogeneous groups (the ability to relate well to others, the ability to cooperate, and the ability to manage and resolve conflicts); and (3) acting autonomously (the ability to act within the big picture; the ability to form and conduct life plans and personal projects; and the ability to defend and assert rights, interests, limits and needs) [24]. As a literature review result [18-24], In Table 1, is presented a synthesis of the general agreed key competencies that are of great importance for thinking and acting for supporting sustainable development.

Table 1. Key sustainability competencies - literature review [18-24].

\begin{tabular}{|c|l|}
\hline Key competence & \multicolumn{1}{c|}{ Description } \\
\hline $\begin{array}{l}\text { 1. Systems thinking } \\
\text { competency }\end{array}$ & $\begin{array}{l}\text { The ability to recognize and understand relationships, to analyze complex } \\
\text { systems, to perceive the ways in which systems are embedded within } \\
\text { different domains and different scales, and to deal with uncertainty }\end{array}$ \\
\hline $\begin{array}{l}\text { 2. Anticipatory } \\
\text { competency }\end{array}$ & $\begin{array}{l}\text { The ability to understand and evaluate multiple futures - possible, probable } \\
\text { and desirable - and to create one's own visions for the future, to apply the } \\
\text { precautionary principle, to assess the consequences of actions, and to deal } \\
\text { with risks and changes }\end{array}$ \\
\hline $\begin{array}{l}\text { 3. Normative } \\
\text { competency }\end{array}$ & $\begin{array}{l}\text { The ability to understand and reflect on the norms and values that underlie } \\
\text { one's actions and to negotiate sustainability values, principles, goals and } \\
\text { targets, in a context of conflicts of interests and trade-offs, uncertain } \\
\text { knowledge and contradictions }\end{array}$ \\
\hline $\begin{array}{l}\text { 4. Strategic } \\
\text { competency }\end{array}$ & $\begin{array}{l}\text { The ability to collectively develop and implement innovative actions that } \\
\text { further sustainability at the local level and further afield }\end{array}$ \\
\hline $\begin{array}{l}\text { 5. Collaboration } \\
\text { competency }\end{array}$ & $\begin{array}{l}\text { The ability to learn from others; understand and respect the needs, } \\
\text { perspectives and actions of others (empathy); understand, relate to and be } \\
\text { sensitive to others (empathic leadership), deal with conflicts in a group; and } \\
\text { facilitate collaborative and participatory problem-solving }\end{array}$ \\
\hline $\begin{array}{l}\text { 6. Critical thinking } \\
\text { competency }\end{array}$ & $\begin{array}{l}\text { The ability to question norms, practices and opinions; reflect on own one's } \\
\text { values, perceptions and actions; and take a position in the sustainability } \\
\text { discourse }\end{array}$ \\
\hline $\begin{array}{l}\text { 7. Self-awareness } \\
\text { competency }\end{array}$ & $\begin{array}{l}\text { The ability to reflect on one's own role in the local community and (global) } \\
\text { society, continually evaluate and further motivate one's actions, and deal } \\
\text { with one's feelings and desires }\end{array}$ \\
\hline $\begin{array}{l}\text { 8. Integrated } \\
\text { problem-solving } \\
\text { competency }\end{array}$ & $\begin{array}{l}\text { The overarching ability to apply different problem-solving frameworks to } \\
\text { complex sustainability problems and develop viable, inclusive and equitable } \\
\text { solution that promote sustainable development - integrating the above- } \\
\text { mentioned competencies }\end{array}$ \\
\hline
\end{tabular}


The key competencies described in Table 1 are essential for educating sustainability principles, but they have not been focused by formal education and they must be developed in conjunction with basic competencies. Furthermore, the key competencies are mutually interdependent and that is why the integrated problem-solving competency is of great importance. In addition, basic competencies such as communication skills are crucial when approaching or supporting sustainable development [18-24].

Key competencies od the sustainability education must be addressed by the programmes curricula (structure and content of the included modules or courses, even on-line training has been proved as valuable [25]). They must be implemented by choosing adequate pedagogical materials and methods which are customized to the target audience characteristics [24-29]. Additional performance criteria (established for all modules or courses) should be considered for the students, trainees assessment process. Thus, a complete training, education program is designed.

Considering the above considerations on important aspects related to education for sustainable development, in the following chapters there will be presented two training programmes that has been designed in two international consortium and by the financial support of the European Commission (Education, Audiovisual and Culture Executive Agency, EACEA), started from 2013 and that have been/are implemented in Romania.

\section{Case of education for sustainable development}

From the perspective of the research methodological approach, there have been adopted a project-based approach by considering the time perspective and context constrains, as following:

- 2013, using Lifelong Learning Programme (LLP) guidelines and requirements there have been prepared and submitted the LeadSUS project, which has been accepted for financed and contract has been signed with the National Agency for LLP in Romania;

- 2013 - 2015 was the period of 24 month for the LeadSUS project implementation with respect of the contract which was based on the project proposal;

- 2015 - 2018 was a period of exploitation of the LeadSUS project results and knowledge transfer and implementation in research (one $\mathrm{PhD}$ thesis that has been successfully presented and approved) and in the didactical process of the master programmes (engineering and management specialization) through the development of the Sustainability and Risk course and the Leadership in Sustainability one;

- 2018, using Erasmus+ KA2 (Innovation and good practices, Strategic Partnership for VET) guidelines and requirements there have been prepared and submitted the TeachSUS project, which has been accepted for financed and contract has been signed with the National Agency in Romania;

- 2018 - 2020 is the period of 24 month for the TeachSUS project implementation with respect of the contract which was based on the project proposal. Simultaneously, the preparations for the results exploitation - after the financial support of the European Commission stops - in research (a PhD. Student is already enrolled in developing researches related to the climate change topic and is working voluntary in the project, too) and in the didactical process of the master programmes (engineering and management specialization) through the continuous improvement of the didactical and methodological processes of the existing courses. In addition, there is expected a diffusion of the methods and tools designed, developed and tested through the TeachSUS project implementation, to other courses (e.g. Supply Chain Management, Occupational Health and Safety Management, Reengineering etc.).

The proposed approach will be detailed in the following to underline the impact of each project to the related target groups (local, regional and national level will be considered). 


\subsection{LeadSUS project (Leadership in sustainability - sustainability manager)}

The project has been developed in an international partnership consisting of: denkstatt Romania (coordinator and contractor), Politehnica University Timisoara (Romania), Institute National Polytechnique de Grenoble (France), Business Informatics Center Rozman Ltd. (Sloveni), International Software Consulting Network Ltd. Graz (Austria) and European Manufacturing and Innovation Research Association, a cluster leading excellence (EMIRAcle from Belgium) [30]. The main observation on the literature available in 2013, together with the dynamics of the actions imposed by the sustainable development strategies at the international and national levels have been proved that Environmental Manager is gradually morphing into the role of Sustainability Manager. However, the problem for Romania and many other European countries was considered that there was no national standard available for this field and consequently, there did not exists any occupational classification codes or certified trainings [30]. This was the context and the gap that was fulfilled by the LeadSUS project which has established a training and European certification program, considered and proved as a great opportunity for Romanian companies that were able to support the green skills and competencies for their employees (mainly for those having managerial duties and tasks).

LeadSUS project's goal was to develop and provide a training and certification program with the support of the European Certification and Qualification Association (ECQA, www.ecqa.org) that validated the training schema, materials and trainees' competences achieved after they followed the training program (in class and/or on-line) [30]. Thus, there is visible that the project supports the education for sustainable development, based on the exchange experiences, knowledge and innovation of the partners involved in its implementation.

The core of the LeadSUS project was the skill card, which clearly fit the competencies required for becoming a real leader in sustainability. For all the skill elements, training material were provided in several languages (English, Romanian, French) and were/are available on-line (using the facilities of the ECQA e-learning system, developed as a Moodle platform). A pool of test questions was defined, which provides the basis for the trainees' certification process. Figure 1 presents the LeadSUS skill card, which is the basis for the training program structure that has been delivered by the international project consortium members (implementation of training and certification took part in 2014 and 2015). Although LeadSUS skill card reflects the opinion of different experts from different type of organizations that have been consulted in this sense, as the higher education institutions, research and development units, consultant and training companies, and experts, industrial companies, service providers, public bodies, specialists from professional organizations concerned with sustainable development (from different economic sector).

Figure 1 shows the skill card is represented as a tree-map with the first level branches consists of the skill units $(U)$ and the second level branches that are the skill elements $(E)$. The third level branches are allocated to the performance criteria $(P C)$ related to each element (directly linked with the examination questions used in the certification process). This representation of the skill card allowed an optimal visualization of the completely developed work and the harmonization and integration of the partners' contributions in order to attend the project objectives. In addition, trainees have the global view of the training and certification program. 


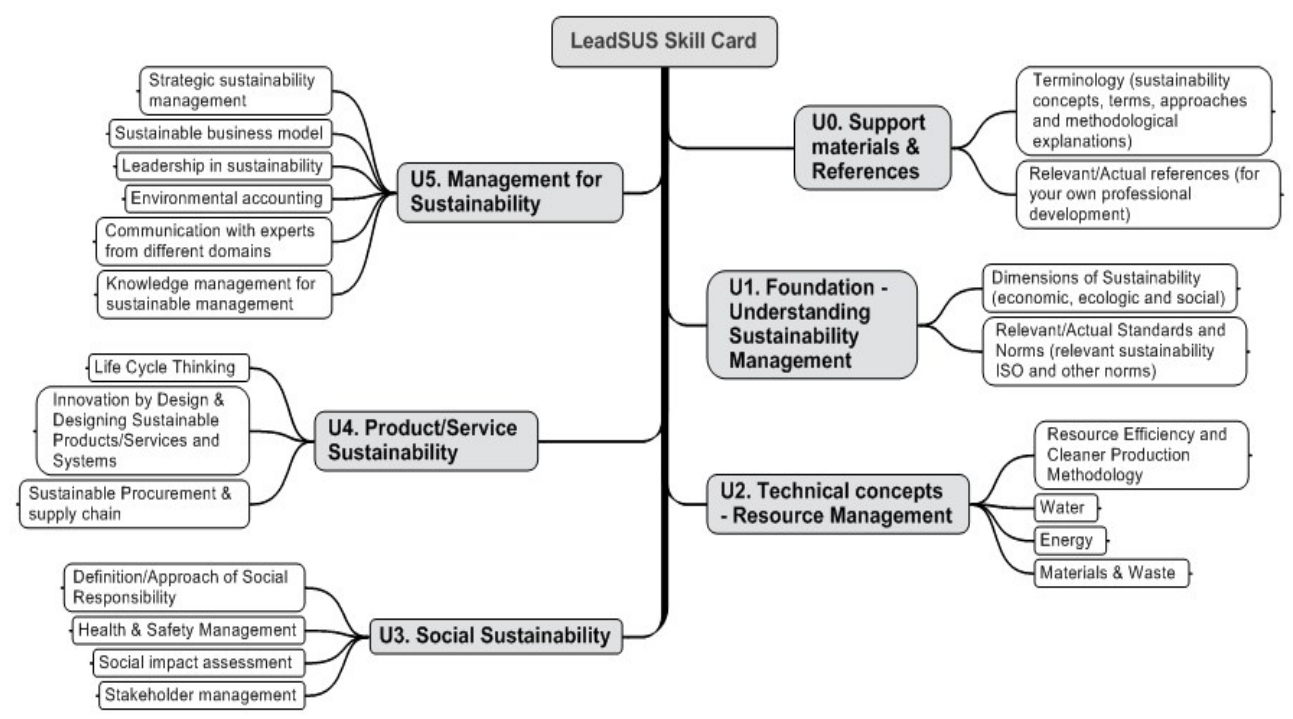

Fig. 1. LeadSUS skill card (the core for the leadership in sustainability competencies development through the designed training program).

The training and certification program have been developed as an interdisciplinary one including knowledge from different fields of sciences as engineering (for U2 and U4), social sciences (as partially for U1 and for U3) and managerial one (as partially for U1 and for U5). Training materials were delivered as PowerPoint presentation and as multimedia materials (audio-video lessons), all of them being available on-line on the learning platform of ECQA (after the trainee is registered, he/she has access to the learning materials and to the exam for certification area).

In the phase of the LeadSUS training and certification program implementation more than 1,000 people were targeted by the project activities, from which almost 200 people from different organizations (different ages and managerial positions) have been trained and certified, in Romania. Furthermore, the Leadership in Sustainability Guide (printed in Romanian and English languages) has been proved as a valuable result to ensure the sustainability of the project through the summarize training material presented in the Guide.

\subsection{TeachSUS - Teaching and educating for Sustainability}

The preliminary facts (researches, statistic data, reports available in the beginning of 2018) that have been considered for the project proposal were related to: (1) the new tendencies in approaching and positioning the education for sustainable development announced by OECD Report in 2018 [32]; the work and key publications of the UNESCO through Global Action Programme on Education for Sustainable Development [33]; (3) the recent published study of Accenture analysis conclusions, they suggest three remedies [34]:

- " "Speed up Experiential Learning - From design thinking in the board room to simulation training tools for technical roles; from on-the-job training initiatives to apprenticeships. Apply new technologies like virtual reality and artificial intelligence (AI) to make learning more immersive, engaging and personalized;

- Shift focus from Institutions to Individuals - Incentivize everyone to develop a broader blend of skills, rather than only targeting the output of institutions in terms of graduates or certifications; 
- Empower Vulnerable Learners - Support older workers, those in lower skill roles or in smaller businesses, who can be more vulnerable to work dislocation and have less access to training. Offer more guidance to follow appropriate training and career pathways. Provide modular learning to suit their life commitments. Provide new funding models, such as grants, to encourage personal lifelong learning plans".

Having the positive experience with LeadSUS project in Romania, there have been developed a market analysis (in 2018) for the identification of the training needs in the field of sustainable development education with a target group consisted of pre-university professors and trainees. The research results have proved that the LeadSUS skill card can be adapted for a new training program for this new target group with some additional units and a specific way of teaching and educating (pedagogy and methodology) mostly using gamification (like the new experiences provided by [36,37]).

Based on the above arguments and facts, there have been developed a coherent and logical frame for teaching and educating sustainability which have been the bases of the TeachSUS project development in 2018 (under the framework and guidelines of ERASMUS+, KA2 Cooperation for Innovation and the Exchange of Good Practices, KA204 - Strategic Partnerships for adult education), approved to be finance and that starts on the $1^{\text {st }}$ of December 2018. The project has been developed and it is implemented through an international partnership consisting of: West University of Timisoara (Romania, coordinator and contractor), denkstatt Romania, Politehnica University Timisoara (Romania), Business Informatics Center Rozman Ltd. (Sloveni), “I AM THE BEST” Talent Mentoring Public Benefit Nonprofit Ltd. Budapest (Hungary) and European Manufacturing and Fundação da Juventuden, Porto (Portugal) [35].

Partners cover a wide range of educational levels, from pre-university level, to university and continuous learning and bring their experiences in diverse forms of education/training for youth and adults, from formal to non-formal education, talent management, career guidance and support, integration of young people into active life and professional activities, entrepreneurship, initiative support and integration in society. Both parts, the universities, companies and NGO's involved in the project have a common (and long demonstrated) interest in improving education and experience in developing and providing new curricula and courses, in improving educational and assessment tools, individually and/or in cooperative projects. Thus, the created international partnership of the TeachSUS project will be able to address to the following topics related to the ERASMUS+ KA2 program: creativity and culture, environment and climate change and quality improvement institutions and/or methods (including school development).

The general objective of the TeachSUS project is to create a common new non-formal education structure for sustainability in order to enable institution and organizations involved in education and adult training, professional development from all over Europe to plan learning experiences that empower their trainees to develop and evaluate alternative visions of a sustainable future and to work creatively with major stakeholders from economic sector in order to assure the practical link between education for sustainability and real economy and the community needs. The proposed partnership has the appropriate mix of competencies and networks to design and implement a new teaching model for teaching and educating sustainability in the case of lower level institutions than universities (pre-university area) and to establish a coherent practical oriented structure for Sustainable Excellence Centers in Romania, Hungary and Portugal [35]. The excellence centers will create a country/region customized structure to sustain collaboration between stakeholders from various fields of sustainability. Each center will provide information, guidance, coaching and counseling activities made with trainers and tutors coming from private company areas and NGO's. Sustainability Centers will organize LivingLab [38] events on sustainability issues and 
presentations of new technologies and green businesses examples together with live training for new learners [35].

The considered target groups of the TeachSUS projects are: (1) adults - teachers, trainers, mentors - from institutions/organizations involved in education, in adult / professional / youth training - they need a larger perspective about education, to understand the simplicity and complexity of sustainability; (2) students from universities who aims to become teachers, human resources (HR) specialists/managers; they need new methodology/tools to help them become in future efficient professionals in education and HR/ management professions; (3) employees from non-governmental organizations (NGOs).

The core of the TeachSUS project is the skill card, which clearly fit the competencies required for teaching and educating sustainability. For all the skill elements, training material will be provided till the end of 2019 and they will be available on-line (using the facilities of the e-learning system associated to the Sustainable Excellence Center in Romania). A pool of test questions was defined, which provides the basis for the trainees' examination process. Figure 2 presents the TeachSUS skill card, which is the basis for the training program structure, already discussed by the project partners (implementation of trainings will took part in 2019-2020).

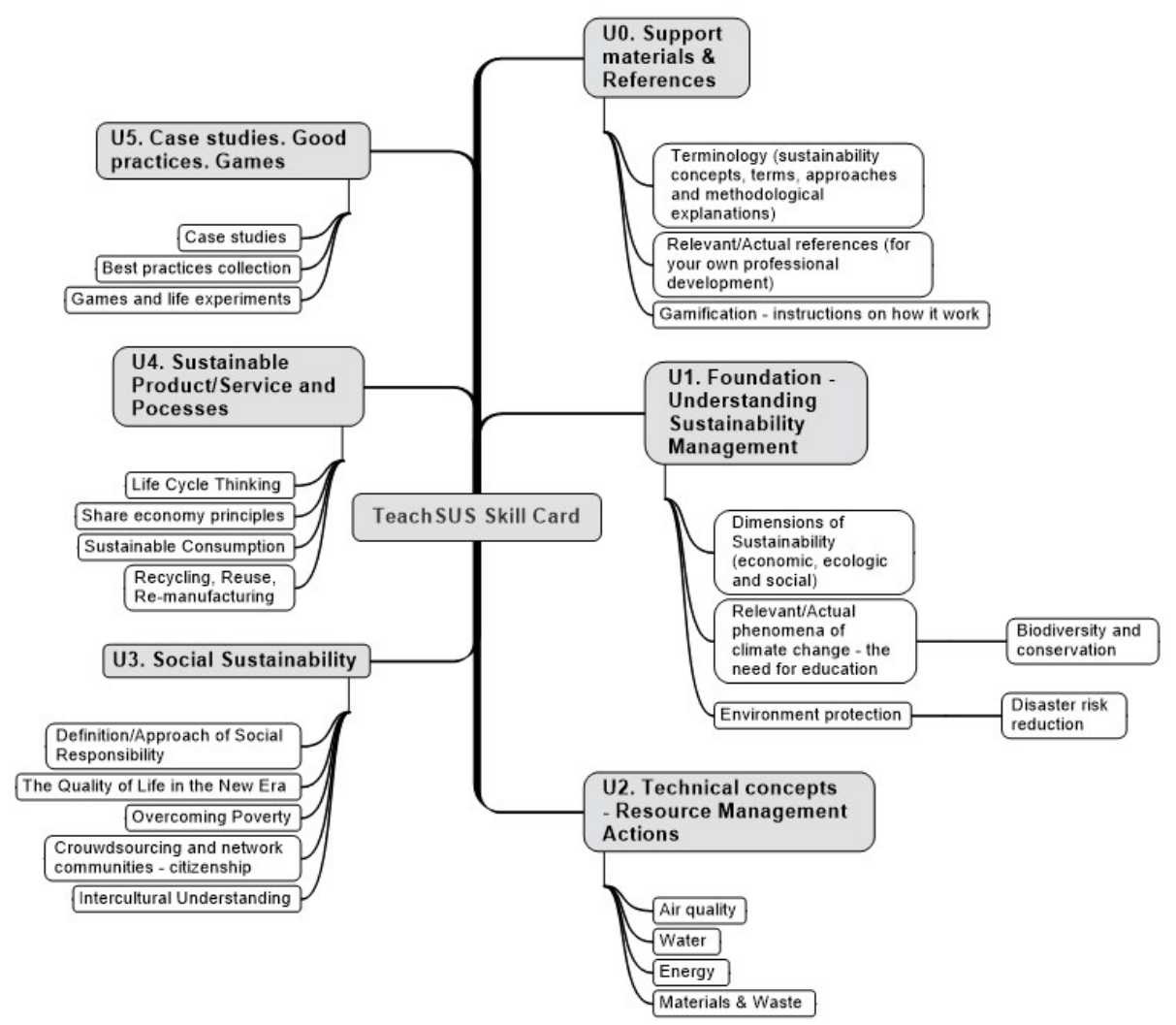

Fig. 2. TeachSUS skill card (first draft, core for the teaching and educating sustainable development).

The specific objectives and results of the TeachSUS project will be [35]:

- A new learning methodology for sustainability, developed through cooperation and exchange of practice between teachers/trainers and the staff responsible to support 
services at different educational levels, in that way that suite the most for the market needs, made available as open, digital resource;

- A new course, and related learning materials and tools for adult learners, that will bring more insights for those which train sustainability or only specific concepts thought their education series in English languages for broad dissemination (translated in Romanian, Slovenian, Hungarian and Portuguese); more than 60 trainees will be trained online during the project implementation period;

- Creation of flexible digital resource, which could add value to any type of training in the field that took place in universities or high schools (pre-university level) and which should integrate topics about sustainability.

\section{Critical analysis on the education for sustainable development in Romania}

After the presentation of developed skill cards related to educational programs in sustainable development filed (related to the LeadSUS and TeachSUS projects), a critical analysis of the implementation potential will underline the strengths and weakness of the actual educational system of higher education to assimilate and implement the proposals (tested and validated with a significant group of trainees). The analysis is based on the training needs analysis developed in 2016 and 2018 for both projects' definition and adaptation toon the Romanian market (target groups are related to those involved in the projects). The results are presented in Table 2 and underline the strengths and weakness of the specific market but also of the actual educational system of higher education, with some important testimonies of other authors.

Table 2. Critical analysis on the education for sustainable development (ESD) in Romania with observations to the actual educational system of higher education.

\begin{tabular}{|c|c|c|}
\hline Ref. to & Strengths & Weaknesses / Challenges \\
\hline Romania & $\begin{array}{l}\text { - For companies, there are } \\
\text { differences between the } \\
\text { training needs for top- } \\
\text { management and other levels } \\
\text { of managers and between } \\
\text { managers and other employees. } \\
\text { LeadSUS schema can be } \\
\text { adapted to these needs easy } \\
\text { (already proved); } \\
\text { - The market need for ESD is } \\
\text { very high and the existing } \\
\text { providers and found available } \\
\text { are not enough to satisfy these } \\
\text { needs; } \\
\text { - In each Region there are } \\
\text { important and very active } \\
\text { actors for ESD } \\
\text { - Big companies and NGOs are } \\
\text { the most important actors, } \\
\text { stakeholders of ESD }\end{array}$ & $\begin{array}{l}\text { - The discrepancies between the rural areas' } \\
\text { economic development and the urban one } \\
\text { could be considered as barriers in the EDS } \\
\text { programms development and } \\
\text { implementation; } \\
\text { - "... research clearly indicate the need to } \\
\text { rethink educational policies for sustainable } \\
\text { development that aim at developing social, } \\
\text { economic and environmental knowledge } \\
\text { that will, ultimately, assist pupils in } \\
\text { tackling the problems of modern life" [43]; } \\
\text { - "...recommend partnerships among } \\
\text { institutions to provide teachers with } \\
\text { efficient training programs; ensure } \\
\text { multicultural contexts to help them } \\
\text { understand diversity and practice tolerance; } \\
\text { work closely with parents, colleagues and } \\
\text { the community; reflect and improve upon } \\
\text { their didactic activity as far as EDS is } \\
\text { concerned" [43]. } \\
\text { - Disadvantage target groups of population } \\
\text { were not targeted by LeadSUS and } \\
\text { TeachSUS initiatives and were not } \\
\text { implemented in all Regions of the country; }\end{array}$ \\
\hline
\end{tabular}




\begin{tabular}{|c|c|c|}
\hline $\begin{array}{l}\text { Higher } \\
\text { education }\end{array}$ & $\begin{array}{l}\text { - Through an adequate } \\
\text { curriculum design that it is } \\
\text { possible to infuse ESD } \\
\text { competencies into the present } \\
\text { curriculum without many costs; } \\
\text { - Knowledge can be easy diffused } \\
\text { in many university programmes } \\
\text { and in the PhD researches; } \\
\text { - Students and young teaching } \\
\text { staff (most female) are very } \\
\text { sensitive to the ESD; } \\
\text { - LeadSUS and TeachSUS } \\
\text { schemas can support the train } \\
\text { the trainers' activities; } \\
\text { - LeadSUS and TeachSUS } \\
\text { schema can be easy transfer to } \\
\text { any e-learning platform which } \\
\text { exist in the universities }\end{array}$ & $\begin{array}{l}\text { - The accreditation system (quality } \\
\text { assurance) of the university programms } \\
\text { introduce delays in satisfying the training } \\
\text { needs of the market; } \\
\text { - Syllabus content up-date and aligned with } \\
\text { the tendencies for ESD is missing (except } \\
\text { the subjects directly linked with } \\
\text { sustainability); }\end{array}$ \\
\hline $\begin{array}{l}\text { Testimonies } \\
\text { from other } \\
\text { similar } \\
\text { researches }\end{array}$ & $\begin{array}{l}\text { "Economic higher education } \\
\text { system in Romania has started } \\
\text { with small steps to adapt to the } \\
\text { environmental requirements. [...] } \\
\text { Romanian public universities are } \\
\text { more involved than private } \\
\text { universities in the implementation } \\
\text { of programs, projects, debates and } \\
\text { courses on sustainable } \\
\text { development and students' } \\
\text { reactions are positive" [40]. "The } \\
\text { present structure of the teacher } \\
\text { training system can be described } \\
\text { as a good practice example } \\
\text { concerning higher education } \\
\text { professional development or as an } \\
\text { alternative that is worthy to be } \\
\text { taken into consideration for other } \\
\text { countries with similar educational } \\
\text { systems by or by } \\
\text { countries/universities that believe } \\
\text { that pedagogical training } \\
\text { addressing ESD should be } \\
\text { completed early in one's teaching } \\
\text { career" [41]. "Stakeholders } \\
\text { expressed highly favourable } \\
\text { opinions of the university's } \\
\text { dealings with different } \\
\text { sustainability aspects ... its } \\
\text { establishment of an attractive and } \\
\text { innovative educational } \\
\text { programme, in compliance with } \\
\text { sustainability principles, } \\
\text { environmental protection and } \\
\text { modern attitudes towards society" } \\
\text { [42] y }\end{array}$ & $\begin{array}{l}\text { "The efforts still required to be made are } \\
\text { significant, since it is observed that all } \\
\text { undergraduate, postgraduate and PhD require } \\
\text { a change of attitude and mentality" [40]. "The } \\
\text { present Romanian teacher training curriculum } \\
\text { does not nurture ESD competencies, and it } \\
\text { does not have this purpose at all" [41]. } \\
\text { "Infusing ESD into the present teacher training } \\
\text { program constitutes a practical solution, which } \\
\text { carries great social impact" [41]. }\end{array}$ \\
\hline
\end{tabular}




\section{Conclusions and future work}

We all are confronted with tremendous problems and social crises, created by our socio-economic models and human behaviors. Approaching sustainable economic behavior in the case of companies and creation/sharing of green products and services - that contribute not only to the sustainable development of companies, but also of local and national economies and to preserve a healthy environment and social security - are difficult tasks, that depend of the involvement of the companies' employees and all other stakeholders that contribute to the life cycle of the products, but also depend of the consumers behavior and the community decisions. We can't expect that only the responsible companies will produce the substantial shifts that we need (which is requested rapidly) in order to create a green economy and save the Planet and his inhabitants. Therefore, we consider that is necessary to approach the sustainable development issues earlier (urgent), starting with schools' programs (pre-university education), by introducing specific knowledge both, in schools' curriculum, especially in approaching science subjects, and in non-formal education activities, in programs dedicated to developing social and life abilities and action of social-entrepreneurship abilities.

Nowadays in Romania, knowledge about why sustainability should be guiding life style (in our day to day life) and about the effects of climate change is very low; teachers are frequently confronted with difficulties in answering to some simple questions of pupils or students. The challenge should be transformed into opportunities of education and learning in a new way about what are the real challenges of our life and how we can face them. Furthermore, an important aspect is related to the behavior change paradigm very fast into a custom human and civilized behavior concerning environment problems. Thus, we must be aware about our activities, actions and their impacts. To do that we have to understand first WHY, and if we will know HOW to do it and change our behavior, this will positive affect all of us during the next decades.

Therefore, new training schemas and training programs will be very helpful for those who have the responsibility to develop skills, change attitudes and form characters. Teachers of the future (actual students) must understand the simplicity and complexity of sustainability.

"Education is the most effective means that society possesses for confronting the challenges of the future". Indeed, education will shape the world of tomorrow. Progress increasingly depends upon the products of educated minds: upon research, invention, innovation and adaptation. Furthermore, educated minds and instincts are needed not only in laboratories and research institutes, but in every walk of life [39].

\section{Acknowledgement}

We would like to express our gratitude for the collaborative work developed with our international partners involved in the LeadSUS and TeachSUS projects. Because of the common vision on the great importance of education for sustainable development we have developed successful training programs and actions that have mobilized the eco-spirits. Hope we will continue working together!

The paper is linked with the research activities related to the following projects: "LeadSUS - Leadership in Sustainability - Sustainable Manager" (LLP-LdV/TOI/2013/RO/022) and "TeachSUS - Teaching and educating for Sustainability" (2018-1-R001-KA204-049253), founded with support of the European Commission. This paper and the related communication reflect the view only of the author, and the Commission cannot be held responsible for any use, which may be made of the information contained therein. 


\section{References}

1. UNESCO, Education 2030: Incheon Declaration and Framework for Action - Toward Inclusive and Equitable Quality Education and Lifelong Learning for All. Paris: UNESCO (2015a).

Available at: http://uis.unesco.org/sites/default/files/documents/education-2030-incheonframework-for-action-implementation-of-sdg4-2016-en 2.pdf (Accessed March 15, 2019).

2. UNESCO, Rethinking Education: Towards a Global Common Good? Paris: UNESCO 2015b. Available http://www.unesco.org/new/fileadmin/MULTIMEDIA/FIELD/Cairo/images/RethinkingEducatio

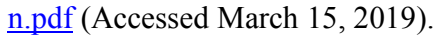

3. L. F. Johnston (Ed.), Higher education for sustainability: Cases, challenges, and opportunities from across the curriculum. Routledge (2013)

4. J. Marcus, N.C. Coops, S. Ellis, J. Robinson, Embedding sustainability learning pathways across the university. Curr. Opin. Env. Sust., 16, 7-13 (2015)

5. M. Backman, H. Pitt, T. Marsden, A., Mehmood, E. Mathijs, E. Experiential approaches to sustainability education: Towards learning landscapes. Int. J. Sust. Higher Ed., 20(1),.139-156 (2019)

6. K. Soini, A. Jurgilevich, J. Pietikäinen, K. Korhonen-Kurki, Universities responding to the call for sustainability: A typology of sustainability centres. J. Clean. Prod., 170, 1423-1432 (2018)

7. G. Tejedor, J. Segalàs, M. Rosas-Casals, Transdisciplinarity in higher education for sustainability: How discourses are approached in engineering education. J. Clean. Prod., 175, 29-37 (2018)

8. R. Medrick, A Pedagogy for Sustainability Education. Journal of Sustainability Education, 5 (2013)

9. A. Perlstein, M. Mortimer, D. Robertson, H. Wise, Making Sustainable Development Real Through Role-Play: "The Mekong Game" Example. Journal of Sustainability Education, 12 (2017)

10. United Nations, Transforming our world: The 2030 agenda for sustainable development, United Nations (2015). Available at: https://sustainabledevelopment.un.org/content/documents/21252030\%20Agenda $\% 20$ for $\% 20$ Sust ainable\%20Development\%20web.pdf (Accessed March 15, 2019)

11. A. Leicht, J., Heiss, W.J., Byun, Issues and trends in Education for Sustainable Development (Vol. 5). UNESCO Publishing (2018)

12. C.N. Stevenson, Addressing the Sustainable Development Goals Through Environmental Education. In Building Sustainability Through Environmental Education (pp. 121-148). IGI Global (2019).

13. P.M. Senge, B. Smith, N. Kruschwitz, J. Laur, S. Schley, The necessary revolution: How organizations and individuals are working together to create a sustainable world. New York, NY: Doubleday (2008).

14. F. Annan-Diab, C. Molinari, Interdisciplinarity: Practical approach to advancing education for sustainability and for the Sustainable Development Goals. The International Journal of Management Education, 15(2), 73-83 (2017).

15. V. Nolet, Educating for sustainability: Principles and practices for teachers. Routledge (2015)

16. M. Gadotti, Education for sustainability - A critical contribution to the Decade of Education for Sustainable Development. New York: Routledge (2016)

17. M. Storey, S. Killian, P. O'Regan, Responsible management education: Mapping the field in the context of the SDGs. The International Journal of Management Education, 15(2), 93-103 (2017)

18. M. Rieckmann, Learning to transform the world: Key competencies in Education for Sustainable Development, Issues and trends in Education for Sustainable Development, 39 (2018)

19. M. Rieckmann, Future-oriented higher education: which key competencies should be fostered through university teaching and learning? Futures, 44(2): 127-135 (2012)

20. G. de Haan, The development of ESD-related competencies in supportive institutional frameworks. Int. Rev. Educ., 56(2), 315-328 (2010)

21. A. Wiek, L. Withycombe, C.L. Redman, Key competencies in sustainability: a reference framework for academic program development. Sustain. Sci., 6(2), 203-218 (2011) 
22. A. Wiek, M.J. Bernstein, R.W. Foley, M. Cohen, N. Forrest, C. Kuzdas, B. Kay, L. Withycombe Keeler, Operationalising competencies in higher education for sustainable development, In: M. Barth, G. Michelsen, I. Thomas, M. Rieckmann (Eds.), Handbook of Higher Education for Sustainable Development. London: Routledge (pp. 241-260) (2016)

23. D.S. Rychen, L.H. Salganik, (Eds.), Key competencies for a successful life and well-functioning society. Hogrefe Publishing (2003)

24. K. Howells, The future of education and skills: education 2030: the future we want $\mathrm{OECD}$ (2018). Available http://create.canterbury.ac.uk/17331/1/E2030\%20Position\%20Paper\%20(05.04.2018).pdf (Accessed March 15, 2019)

25. C. Li, H. Zhou, Enhancing the efficiency of massive online learning by integrating intelligent analysis into MOOCs with an application to education of sustainability. Sustainability-Basel, 10(2), 468 (2018).

26. B.E. Wood, S. Cornforth, F. Beals, M. Taylor, R., Tallon, Sustainability champions? Academic identities and sustainability curricula in higher education. Int. J. Sust. Higher Ed., 17(3), 342-360 (2016)

27. M. Green, M. Somerville, Sustainability education: Researching practice in primary schools. Environ. Educ. Res., 21(6), 832-845 (2015)

28. C. Wamsler, J. Brossmann, H. Hendersson, R. Kristjansdottir, C. McDonald, P. Scarampi, Mindfulness in sustainability science, practice, and teaching. Sustain. Sci., 13(1), 143-162 (2018)

29. D. Andrews, The circular economy, design thinking and education for sustainability. Local Economy, 30(3), 305-315 (2015)

30. LeadSUS, Leadership in Sustainability - Sustainable Manager, project application form, no. LLP-LdV/TOI/2013/RO/022 (2013)

31. ECQA, European Certification and Qualification Association, Guidelines (2018). Available at: https://www.ecqa.org/index.php?id=221 (Accessed March 13, 2019)

32. K. Howells, The future of education and skills: education 2030: the future we want, OECD report (2018). Available at:

http://create.canterbury.ac.uk/17331/1/E2030\%20Position\%20Paper\%20(05.04.2018).pdf (Accessed March 13, 2019)

33. UNESCO, Key publication - Education for Sustainable Development (2018). Available at: https://en.unesco.org/themes/education-sustainable-development/clearinghouse/publications (Accessed March 14, 2019)

34. Accenture. It's learning. Just Not as we Know it. How to Accelerate Skills Acquisition in the Age of Intelligent Technologies, Research Report (2018). Available at:

https://www.accenture.com/us-en/insights/future-workforce/transforming-learning (Accessed March 13, 2019)

35. TeachSUS, Teaching and Educating for Sustainability, project application form, no. 2018-1R001-KA204-049253 (2018)

36. T. Reiners, L.C. Wood (Eds.). Gamification in education and business. Springer (2014).

37. L. Gatti, M. Ulrich, P. Seele, Education for sustainable development through business simulation games: An exploratory study of sustainability gamification and its effects on students' learning outcomes. J. Clean. Prod., 207, 667-678 (2019)

38. J. von Geibler, L. Erdmann, C. Liedtke, H. Rohn, M. Stabe, S. Berner, ... K. Kennedy, Exploring the potential of a German Living Lab research infrastructure for the development of low resource products and services. Resources, 3(3), 575-598 (2014)

39. G. Lueddeke, Global population health and well-being in the 21st century: toward new paradigms, policy, and practice. Springer Publishing Company (2015)

40. I. Novo-Corti, L. Badea, D.M. Tirca, M.I. Aceleanu, A pilot study on education for sustainable development in the Romanian economic higher education. Int. J. Sust. Higher Ed., 19(4), 817-838 (2018)

41. D.E. Dumitru, Reorienting higher education pedagogical and professional development curricula toward sustainability - a Romanian perspective. Int. J. Sust. Higher Ed., 18(6), 894-907 (2017)

42. D.C. Dabija, C. Postelnicu, V. Dinu, A. Mihăilă, Stakeholders' perception of sustainability orientation within a major Romanian University. Int. J. Sust. Higher Ed., 18(4), 533-553 (2017) 
43. I. Lampă, A. Greculescu, L.L. Todorescu, Education for sustainable development-Training the young generation for the Future. Procedia-Social and Behavioral Sciences, 78, 120-124 (2013) 